\title{
Thermostability and thermodynamic characterization of sprouted pearl millet a-amylases for its biotechnological applications
}

\author{
K. U. Agbo*, P. C. Okwuenu, A. L. Ezugwu, S. O. O. Eze and F. C. Chilaka \\ Department of Biochemistry, University of Nigeria, Nsukka, Nigeria
}

\begin{abstract}
There is an increasing demand for amylolytic products such as glucose syrup in biotechnological industries. Starch liquification by $\alpha$-amylase must take place at temperatures higher than the gelatinization temperatures and the use for thermostable $\alpha$-amylase is therefore required. Two (or) isotypes namely amy- 1 and amy- 2 of $\alpha$-amylase from pearl millet have been investigated for their thermostability and thermodynamic characterization.Thermal inactivation of $\alpha$-amylase follows first order kinetics which varies with time and product during inactivation process. The half-life of $\alpha-1$ was 198 mins at $50^{\circ} \mathrm{C}$. The $E a$ (inact) was calculated using Arrhenius plot gave $22.00 \mathrm{KCalmol}^{-1} \mathrm{~K}^{-1}$ for $\alpha-1$ and 19.44 $\mathrm{KCalmol}^{-1} \mathrm{~K}^{-1}$ for $\alpha-2$. The Z-values were $22.52^{\circ} \mathrm{C}$ and $25.38^{\circ} \mathrm{C}$ for $\alpha-1$ and $\alpha-2$, respectively. The thermodynamic parameters: the enthalpy change of inactivation $\Delta \mathrm{H}$ (inact) had $87.815 \mathrm{KJmol}^{-1} \mathrm{~K}^{-1}$ at $50^{\circ} \mathrm{C}$ for $\alpha-1$ and $78.56 \mathrm{KJmol}^{-1} \mathrm{~K}^{-1}$ at $50^{\circ} \mathrm{C}$ for $\alpha-2$. The change in free energy of inactivation $\Delta \mathrm{G}$ (inact) of $\alpha-1$ and $\alpha-2$ were $105.5 \mathrm{KJMol}^{-1} \mathrm{~K}^{-1}$ and $104.33 \mathrm{KJMol}^{-1} \mathrm{~K}^{-1}$ at $50^{\circ} \mathrm{C}$, respectively. The entropy of inactivation $\Delta \mathrm{S}$ (inact) values for $\alpha-1$ and $\alpha-2$ are calculated as $-54.80 \mathrm{JMol}^{-1} \mathrm{~K}^{-1}$ and $-79 \mathrm{JMol}^{-1} \mathrm{~K}^{-1}$ at $50^{\circ} \mathrm{C}$. This suggest that the $\alpha-1$ and $\alpha-2$ are thermostable.
\end{abstract}

Keywords : Thermostability; Biocatalysts; Thermodynamic; Millet; Inactivation

\section{Introduction}

Catalyst speeds up the turning of reactants to products but doesn't undergo any permanent change. Catalyst acts by reducing the energy barrier of chemical reactions, by producing a dramatic increase in reaction rates from $10^{6}-10^{24}$. Catalysts found in a living system are called biocatalysts. Amylases are enzymes that catalyze the conversion of starch and other related polysaccharides possessing $\alpha-1,4$ glycosidic bonds into simpler derivatives such as oligosaccharides or monosaccharides. The enzyme has been purified from few plants such as barley, sorghum, soybeans, millet, wheat (Thoma et al., 1971), wheat germ (Sharma et al., 2000), maize (Warner and Knutson, 1991). Carbohydrate based agricultural products such as starch occur abundantly in some developing countries of the tropics (Okolo et al., 1995). Pearl millet (Pennisetum glaucum) belongs to the family of Poaceae. It is grown under conditions of high temperature (thermophile) and low rainfall (Ambasht and Kharkrang, 2012). Cereal $\alpha$-amylases have gained importance in processes due to their suitability for biotechnological application in industries like food, brewing, detergents, paper and textile. The enzyme is important for diagnosis of pancreatitis (Ambasht and Kharkrang, 2012). Conversion of starch to various sweeteners is achieved through a chemical (acid) or enzymatic process. However, the use of enzyme is preferred to acid, because it produces high yields of desirable products and less formation of undesirable products such as toxic compounds (Sanjust et al., 2004; Chaplin, 2004). Temperature and chemicals promote enzyme inactivation. Temperature variation may opposed effects on enzyme activity and stability and it is therefore a key variable in any biocatalytic process (Wasserman, 1984). Biocatalyst stability i.e the capacity to retain activity over time is undoubtedly the limiting factor in most bioprocesses, biocatalyst stabilization being a central issue of biotechnology (Illanes, 1999). Biocatalyst thermostability allows a higher operation temperature, which is clearly advantageous because of higher reactivity, higher process yield, lower viscosity and fewer contamination problem (Mozhaev, 1993). Enzyme thermal inactivation is the consequence of weakening the intermolecular forces responsible for the preservation of its $3 \mathrm{D}$-structure, leading to a reduction in its catalytic capacity (Misset, 1993). Inactivation may involve covalent or non-covalent bond disruption with subsequent molecular aggregation or improper folding (Bommarius and Broering, 2005). Knowledge of enzyme inactivation kinetics under process condition is an absolute requirement to properly evaluate enzyme performance (Illanes et al., 2008).Various thermostability parameters, such as half life of the enzyme preparation $\left(T_{1 / 2}\right)$, the activation energy of thermal 
denaturation $\left(E a_{D}\right)$, enthalpy of activation of the thermal denaturation $\left(\Delta H_{D}\right)$, entropy of activation of thermal denaturation $\left(\triangle S_{D}\right)$ and the Gibbs free energy of activation of thermal denaturation $\left(\Delta G_{D}\right)$ were used to evaluate the thermostability of $\alpha$-amylase extracted from germinating pearl millet. The search for new or improved heat stable $\alpha$-amylase has been the subject for research and discussion. Though thermophilic microorganisms seems to be promising in the production of thermostable enzymes, the technological use of these organisms is faced with challenges since knowledge on physiology and genetics of such organism is poor, they are fastidious, grow slowly and not recognized as safe (Illanes, 1999). Hence, an alternative source of thermally stable $\propto$ - amylase suitable for biotechnological industries is required for production processes.

\section{Materials and methods}

The $\propto$ - amylase used in this study was donated by the enzymology research unit, Department of Biochemistry, University of Nigeria, Nsukka as requirement for the work. Unless indicated otherwise, all chemicals used in the present investigation were of high quality analytical grade.

\section{Processing of cassava starch}

Cassava starch was processed using the method described by Corbishley and Miller (1984).

\section{Protein content determination}

Protein content of the enzyme solution was determined by the method of Lowry et al. (1951) using Bovine Serum Albumin (BSA) as standard.

\section{Determination of enzyme activity}

Amylase activity was determined using dinitrosalicyclic acid (DNSA) as described by Bernfeld (1951). One unit of amylase activity was expressed as the amount of enzyme which released one micromole ( $\mu$ mole) of the reducing equivalent (maltose) per minute under assay conditions. Amylase activity was estimated by the amount of reducing equivalent (maltose) released during the hydrolysis of the starch.

\section{Thermal inactivation studies}

The activity of each enzyme fraction was assayed at $50^{\circ} \mathrm{C}$ without preheating. This was carried out by using $0.5 \mathrm{ml}$ of each of the enzyme fractions, $1 \%(\mathrm{w} / \mathrm{v})$ starch solutions, and $1 \mathrm{ml}$ of the sodium acetate buffers of $\mathrm{pHs} 4.5$ and 5.5 for the $\alpha-1$ and $\alpha-2$ respectively for 30 mins at optimum temperature $\left(50^{\circ} \mathrm{C}\right)$ to obtain the $\mathrm{A}_{0}$ and these were called heat untreated samples. While the test mixtures were incubated for 2 hours at varying temperatures, $40^{\circ}, 50^{\circ}, 60^{\circ}$ and $70^{\circ} \mathrm{C}$ and at every 30 minute interval, $0.5 \mathrm{ml}$ was taken from each of the fractions, cooled at $4^{\circ} \mathrm{C}$ for 20 minutes so that the enzyme's secondary and tertiary structures became stable after the heat treatment any reversible unfolding reverted back to the native forms (Griffin et al., 1984) then, were assayed at optimum conditions ( $\mathrm{pH}$ of 4.5 and 5.5 for $\alpha-1$ and $\alpha-2$ and then $50^{\circ} \mathrm{C}$ for both amylases) as was done for heat untreated samples. The activity obtained from the samples is called the $A_{t}$.

\section{Determination of percentage residual activity}

The $\%$ residual activity of the enzyme fraction was calculated using the equation 1 below:

At/Ao x 100\% ---------------- Equation 1

Where At $=$ the enzyme activity at time, $t$

$$
A o=\text { the initial enzyme activity at time, } 0
$$

\section{Denaturation constants of the enzyme fraction $k_{d}$}

The $k_{d}$ of the $\alpha$-amylase preparations was estimated as follows. The calculated values of the $\%$ residual activity were tabulated and $k_{d}$, was determined from the slope of plots of In of \%residual activity of various temperatures against time $(t)$ from the equations 2 below:

$A t / A o=\exp (-k d t)---------------$ Equation 2

$\operatorname{In}\left(\frac{A t}{A o}\right)=-k d t$ first order kinetics

Where $k d=$ denaturation constant of the enzyme

$$
t=\text { time }
$$

Half-life of the enzyme solution $t_{1 / 2}$

The $t_{1 / 2}$ was obtained from the following equation:

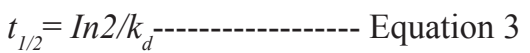

Activation energy of inactivation $E_{\text {(inact) }}$

The $\mathrm{Ea}_{\text {(inact) }}$ was obtained from the Arrhenius equation:

Ink $=\mathrm{Ae}$-EaR/T----------------Equation 4

where $k d$ is the first order rate constant of thermal inactivation of the enzyme activity, obtained through the slopes of the plots described above.

Calculation of D-values of the enzyme fractions

The $D$-values (decimal reduction time or time required to 
preincubate the enzyme at a given temperature to maintain $10 \%$ residual activity) of the enzyme fractions were calculated from the formula below:

$D=\frac{\operatorname{In} 10}{k d}$ -Equation 5

Calculation of Z-Values of the enzyme fractions

The $Z$-value (temperature rise necessary to reduce the $D$ value by one logarithmic cycle (Pal et al., 2011) was calculated from the slope of the graph between $\log \mathrm{D}$ vs temperature $\left({ }^{\circ} \mathrm{C}\right)$ using the equation and the results were presented in the table below:

Slope $=\left(-\frac{1}{z}\right)$-----------------equation 6

\section{Thermodynamics parameters}

The enthalpy of activation of thermal denaturation $\Delta H_{\text {(inact) }}$, which is the amount of energy required to bring the enzyme to the activated state for the subsequent denaturation at a given temperature, Gibbs free energy of activation of the thermal denaturation $\left(\Delta G_{\text {(inact }}\right)$ and the entropy of activation of the denaturation $\left(\Delta S_{\text {(inact) }}\right)$ were calculated through the following equations (Siddiqui et al., 1997; Riaz et al., 2007).

$\Delta H_{\text {(inact) }}=E a_{\text {(inact) }}-R T$------------------- Eqaution 7

Where $\Delta H_{\text {(inact) }}=$ change in enthalpy of inactivation

$E a_{\text {(inact) }}=$ activation energy of inactiavation

$R=$ general gas constant

$T=$ temperature

$\Delta G_{\text {(inact) }}=-R T \times \operatorname{In}\left(\frac{K d \times h}{K b \times T}\right)$---------------- Equation 8

Where $\Delta G_{\text {(inact) }}=$ free energy change of inactivation $h=$ Plank's constant

$K b=$ Bolztman constant

$\Delta S_{\text {(inact) }}=\frac{\Delta H_{\text {(inact) }}-\Delta G_{\text {(inact) }}}{T}$

$\Delta S=$ change in entropy of inactivation

\section{Results and discussion}

From the gel filtration profile of the purified enzyme, it was observed that the enzyme has three different isotypes, two of them (amy1 and amy2) were used for further studies.
Determination of denaturation constant $(K d)$

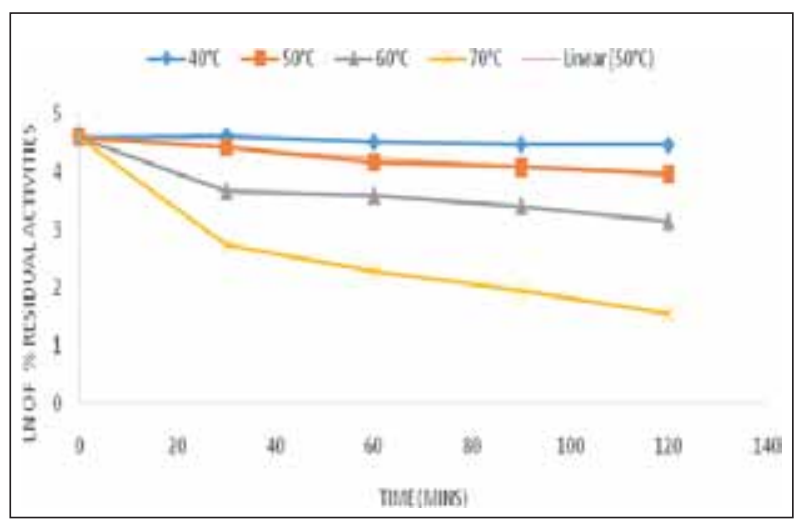

Fig. 1. Percentage residual activity against time for fraction one $(\alpha-1)$

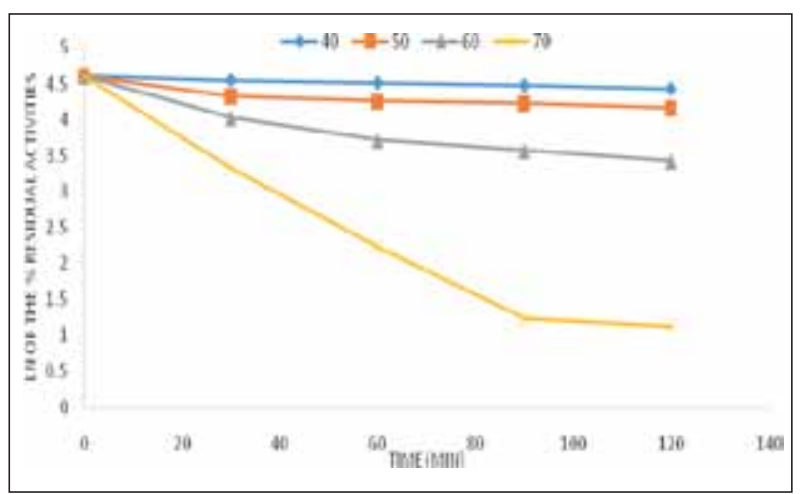

Fig. 2. Percentage residual activities against time for fraction two $(\alpha-2)$

Determination of Z-values of the two isotypes

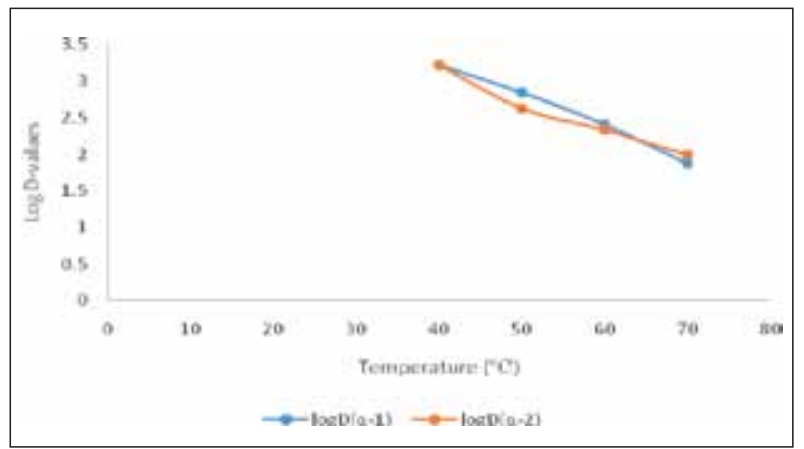

Fig. 3. Calculation of $\mathrm{Z}$-value for the two isotypes ( $\alpha-1$ and $\alpha-2)$ 
Determination of activation energy of inactivation of the two enzyme isotypes

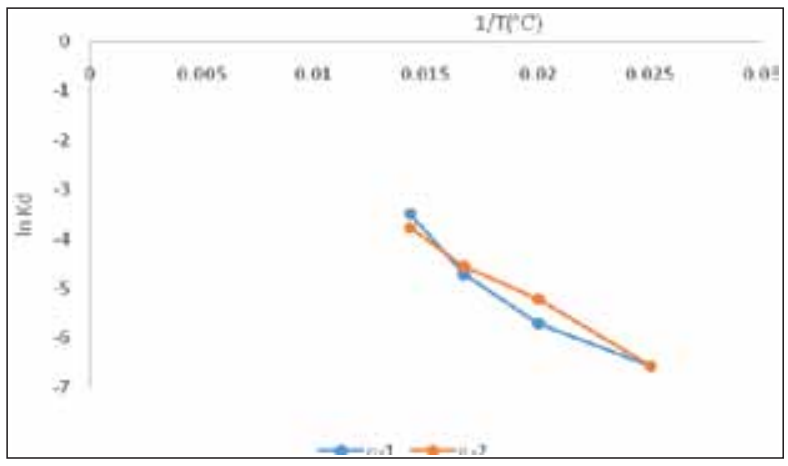

Fig. 4. Arrhenius plot for determination of activation energy of inactivation for $\alpha-1$ and $\alpha-2$

Various data were obtained from the plots above and summarized in the tables below:
Enzymes in general are protein molecules with precise primary, secondary and tertiary structures based on their amino acid sequences. Heating can denature the enzymes, i.e., the enzymes lose their secondary, tertiary and quaternary (if present) structures which are essential for their activities (Petsko and Ringe, 2004). Thermostability of an enzyme refers to its resistance to unfolding upon heating. Thermal denaturation occurs in two steps.

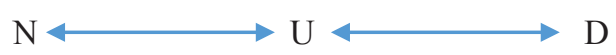

$\mathrm{N}$ is the native, $\mathrm{U}$ is the unfolded enzyme which could be reversibly refolded upon cooling and I (D) is the inactivated enzyme formed after prolonged exposure to heat and therefore cannot be recovered by cooling. Various kinetics and thermodynamics parameters have been effectively used

Table I. Summary of the thermoinactivation and thermodynamics of the enzyme denaturation for fraction one (a-1)

\begin{tabular}{llcllll}
\hline Temperature $\left({ }^{\circ} \mathrm{C}\right)$ & $T_{1 / 2}(\mathrm{~min})$ & $\mathrm{K}_{\mathrm{d}}(\mathrm{min}-1)$ & $\begin{array}{l}\mathrm{D} \text {-values } \\
(\mathrm{mins})\end{array}$ & $\begin{array}{l}\Delta \mathrm{H}^{\mathrm{o}}(\mathrm{D}) \\
(\mathrm{kJ} / \mathrm{mol} / \mathrm{K})\end{array}$ & $\begin{array}{l}\Delta \mathrm{G}^{\mathrm{o}}{ }_{(\mathrm{D})} \\
(\mathrm{kJ} / \mathrm{mol} / \mathrm{K})\end{array}$ & $\begin{array}{l}\Delta \mathrm{S}_{(\mathrm{D})}^{\mathrm{o}} \\
(\mathrm{J} / \mathrm{mol} / \mathrm{K})\end{array}$ \\
\hline 40 & 495 & 0.0014 & 1645 & 87.898 & 104.54 & -0.0532 \\
50 & 198 & 0.0035 & 658 & 87.815 & 105.50 & -0.0548 \\
60 & 72.94 & 0.009 & 242.42 & 87.731 & 106.09 & -0.0551 \\
70 & 22.90 & 0.032 & 76.26 & 87.648 & 106.05 & -0.0536 \\
Ea & $22.00 \mathrm{KCalmol}^{-1} \mathrm{~K}^{-1}=92.4 \mathrm{KJMol}^{-1} \mathrm{~K}^{-1}$ & & & \\
Z-value & $22.52^{\circ} \mathrm{C}$ & & & & &
\end{tabular}

Table II. Summary of the thermoinactivation and thermodynamics of the enzyme denaturation for fraction two (a-2)

\begin{tabular}{lllllll}
\hline Temperature $\left({ }^{\circ} \mathrm{C}\right)$ & $T_{1 / 2}(\mathrm{~min})$ & $\mathrm{K}_{\mathrm{d}}{ }^{\mathrm{min}-1)}$ & $\begin{array}{l}\mathrm{D} \text {-values } \\
(\mathrm{mins})\end{array}$ & $\begin{array}{l}\Delta \mathrm{H}^{\mathrm{o}}(\mathrm{D}) \\
(\mathrm{kJ} / \mathrm{mol} / \mathrm{K})\end{array}$ & $\begin{array}{l}\Delta \mathrm{G}^{\mathrm{o}}(\mathrm{D}) \\
(\mathrm{kJ} / \mathrm{mol} / \mathrm{K})\end{array}$ & $\begin{array}{l}\Delta \mathrm{S}_{(\mathrm{D})}^{\mathrm{o}} \\
(\mathrm{J} / \mathrm{mol} / \mathrm{K})\end{array}$ \\
\hline 40 & 495 & 0.0014 & 1645 & 78.65 & 104.54 & -0.083 \\
50 & 128.33 & 0.0054 & 426.48 & 78.56 & 104.33 & -0.079 \\
60 & 65.38 & 0.0106 & 217.26 & 78.47 & 105.79 & -0.082 \\
70 & 30.13 & 0.023 & 100.13 & 78.39 & 106.85 & -0.083 \\
Ea & $19.44 \mathrm{KCalmol}^{-1} \mathrm{~K}^{-1}=81.243 \mathrm{KJMol}^{-1} \mathrm{~K}^{-1}$ & & & \\
$\mathrm{Z}$-value & $25.38^{\circ} \mathrm{C}$ & & & & & \\
\end{tabular}


in assessing enzyme thermostability and such parameters are: half-life $\left(\mathrm{t}_{1 / 2}\right)$, activation energy of denaturation $\left(\mathrm{Ea}_{(\mathrm{D})}\right)$, the enthalpy of denaturation $\left(\Delta \mathrm{H}_{(\mathrm{D})}\right)$, the change in entropy associated with thermal denaturation $\left(\Delta \mathrm{S}_{(\mathrm{D})}\right)$ and the change in Gibbs free energy during the thermal denaturation $\left(\Delta \mathrm{G}_{(\mathrm{D})}\right)$ (Maragoni, 2003). The plots of the residual activities vs incubation time (Figs. 1 and 2) for the enzymes are linear, showing that the inactivation could be expressed as first order kinetics in the temperature range of $40^{\circ} \mathrm{C}-70^{\circ} \mathrm{C}$.

The half-life $\left(\mathrm{t}_{1 / 2}\right)$ determinations was accurate and reliable especially when computing the stability properties of an enzyme at different temperatures. On the half-life each of the two peaks, a longer half-life was observed at lower temperatures, indicating that the enzyme is more thermally stable at lower temperature. Comparing the two enzymes at their optimum temperature, $\left(50^{\circ} \mathrm{C}\right), \alpha-1$ has half-life of 210 minutes while $\alpha-2$ has 128.33 minutes (Tables I and II). This is an indication that $\alpha-1$ is more thermally stable than $\alpha-2$. The half-life of 23.10 minutes was observed in $\alpha$-amylase sourced from digestive tract of tropical house cricket at $60^{\circ} \mathrm{C}$ (Kouadio, 2013) while the half-life of 8.5 minutes was observed in the $\alpha$-amylase from sorghum bicolar at $60^{\circ} \mathrm{C}$ (Kumar, 2008). Comparing the data above with the present study, 72.94 minutes and 65.38 minutes for $\alpha-1$ and $\alpha-2$ at $60^{\circ} \mathrm{C}$ (Tables I and II), suggesting that the enzyme under study maybe more thermally stable than the cited ones.

Also, the time required to reduce the enzyme activity by $90 \%$ i.e., the D-value is another reliable parameter in assessing enzyme thermostability. Just like the $t_{1 / 2}$, the $D$-values decreased with increase in temperature, showing a decrease in denaturation time as the temperature increases. This implies that the enzyme is thermally unstable at higher temperatures. $\alpha-1$ has D-value of 658 minutes (Table I) while $\alpha-2$ has the D-value of 462.48 minutes (Table II) at their optimal temperature. This indicates that $\alpha-1$ is more stable than $\alpha-2$ at their optimum temperature. The D-values of $\alpha-1$ and $\alpha-2$ from digestive tract of tropical house cricket at $60^{\circ} \mathrm{C}$ were obtained 76.77 minutes and 35.43 minutes while in the present study, 242.42 minutes and 217.26 minutes for $\alpha-1$ and $\alpha-2$, respectively at the same temperature (Tables I and II). This could be an indication of high thermostability of this enzyme. Thermal denaturation of enzymes requires an input of a minimum amount of energy known as activation energy of denaturation $\left(\mathrm{Ea}_{(\mathrm{D})}\right)$ which must be supplied to the native enzyme in order to initiate the denaturation process. The denaturation process proceeds through an unstable intermediate transition (or activated) state, U (Siddiqui et al., 1997). As long as the initial input of energy is less than the
$\mathrm{Ea}_{(\mathrm{D})}$ the unstable intermediate (U) can fold back into the native state $(\mathrm{N})$ upon cooling (Saqib et al., 2010). This activation barrier is crucial to the stability and survival of the biomolecules in nature. Once the $\mathrm{Ea}_{(\mathrm{D})}$ barrier has been overcome, the enzyme is denatured (I) and cannot refold to the native form. This is known as the irreversible thermal denaturation of the enzyme (Siddiqui et al., 1997; Javed et $a l ., 2009)$. The $\mathrm{Ea}_{(\mathrm{D})}$ was calculated from the lines of best fit from the Arrhenius plots of the rate of thermal denaturation $\left(\mathrm{K}_{\mathrm{d}}\right)$ versus temperature (Fig. 4) which were $22.00 \mathrm{kcalmol}^{-1} \mathrm{k}^{-1} \quad\left(92.4 \mathrm{KJmol}^{-1} \mathrm{~K}^{-1}\right)$ and $\quad 19.44 \mathrm{Kcalmol}^{-1} \mathrm{k}^{-1}$ $\left(81.243 \mathrm{KJmol}^{-1} \mathrm{k}^{-1}\right.$ ) (Tables I and II) for $\alpha-1$ and $\alpha-2$ respectively. $\mathrm{Ea}_{(\mathrm{D})}$ of $2510 \mathrm{KJmol}^{-1} \mathrm{k}^{-1}$ was obtained from peroxidase from white yam (Eze et al., 2010). $\mathrm{Ea}_{(\mathrm{D})}$ of $245.89 \mathrm{KJmol}^{-1} \mathrm{~K}^{-1}$ and $182.92 \mathrm{KJmol}^{-1} \mathrm{~K}^{-1}$ were obtained from the digestive tract of tropical house cricket $\alpha$-amylase (Kouadio et al., 2013). Duy and Fitter, 2005 reported that the $\mathrm{Ea}_{(\mathrm{D})}$ of $\alpha$-amylase from Bacillus licheniformis to be $53.1 \mathrm{KJmol}^{-1} \mathrm{~K}^{-1}$. The $\mathrm{Ea}_{(\mathrm{D})}$ is directly related to another important thermodynamic parameter, the enthalpy of the activation of the denaturation, $\Delta \mathrm{H}_{(\mathrm{D})}$. It is the total amount of energy required to bring the enzyme from the ground state to the activated intermediate. In the present study, $\Delta H_{(D)}$ values were found to be decreasing as the temperature increased (Tables I and II). The high values of the change in enthalpy of denaturation obtained for thermoinactivation of the $\alpha$-amylases from pearl millet indicated that the enzyme would undergo a considerable change in conformation during denaturation (Marin et al., 2003). The fact that $\Delta \mathrm{H}$ values decreased with increase in temperature reveals that less energy is required to denature the enzyme at high temperature (Bhatti et al., 2006). A similar trend in the values of $\Delta H$ was observed in peroxidase from white yam (Eze et al., 2010) though with different magnitude, $\alpha$-amylase from digestive tract of tropical house cricket (Kouadio et al, 2013), $\alpha$-amylase from sorghum bicolar (Kumar, 2008). As a rule of thumb, the higher the $\mathrm{Ea}_{(\mathrm{D})}$, the higher the $\Delta \mathrm{H}_{(\mathrm{D})}$. Comparing the $\Delta \mathrm{H}_{(\mathrm{D})}$ and $\mathrm{Ea}_{(\mathrm{D})}$ of $\alpha-1$ and $\alpha-2$ obtained in this work, (Tables I and II), the $\mathrm{Ea}_{\text {(D) }}$ of $\alpha-1$ was higher than the $\mathrm{Ea}_{(\mathrm{D})}$ of $\alpha-2$ likewise their mean $\Delta \mathrm{H}_{(\mathrm{D})}$ values. This is an indication that $\alpha-1$ will not easily undergo conformational changes like the $\alpha-2$.

Although a high enthalpy $\left(\Delta \mathrm{H}_{(\mathrm{D})}\right)$ and activation energy of denaturation $\left(\mathrm{Ea}_{(\mathrm{D})}\right)$ would imply that the enzyme would be thermostable, it is important to look at the other parameters, $\Delta \mathrm{G}_{\text {(D) }}$ and $\Delta \mathrm{S}_{\text {(D) }}$ as well. The Gibbs free energy of activation of denaturation $\Delta \mathrm{G}_{(\mathrm{D})}$ is in fact a more reliable indicator of stability (Maragoni, 2003). A smaller or negative value of change in Gibbs free energy indicates spontaneity of a reaction, in this case, enzyme thermal denaturation hence 
lower stability (Maragoni, 2003; Damodaran, 2006). In the present study, there was increase in $\Delta \mathrm{G}_{(\mathrm{D})}$ of both enzyme isotypes (Tables I and II) which is an indication that the enzyme is thermally stable at high temperature. An opposite trend was observed in $\alpha$-amylase from the digestive tract of tropical house cricket (Kuoadio, 2013). A similar trend was also observed in $\alpha$-amylase from sorghum bicolar (Kumar, 2008). Comparing $\alpha-1$ and $\alpha-2$ in the present study, both isotypes gave equal $\Delta \mathrm{G}_{(\mathrm{D})}$ at $40^{\circ} \mathrm{C}$ but experienced a change as the temperature increased (Tables I and II). At their optimum temperature $\left(50^{\circ} \mathrm{C}\right)$, their $\Delta \mathrm{G}_{(\mathrm{D})}$ was calculated to be $105.50 \mathrm{KJmol}^{-1} \mathrm{~K}^{-1}$ and $104.33 \mathrm{KJmol}^{-1} \mathrm{~K}^{-1}$ respectively (tables I and II). This suggests that $\alpha-1$ could be more thermally stable than $\alpha-2$. It is also noteworthy that $\Delta \mathrm{G}_{(\mathrm{D})}$ value, which is a measure of the spontaneity of the inactivation process is higher than the $\Delta \mathrm{H}_{(\mathrm{D})}$ values in both $\alpha-1$ and $\alpha-2$. This is due to the negative entropic contribution during the process (Tanaka and Hoshino, 2002; $\mathrm{Pal}$ and Khanum, 2011). The values obtained here are close to the ones obtained from crude endoglucanase from Aspergillus fumigatus grown under submerged fermentation (Saqib et al., 2010). This is an indication that the two enzymes may have similar amino acid sequence. However, Eze et al. (2010) obtained a negative $\Delta \mathrm{G}_{(\mathrm{D})}$ values from peroxidase of white yam showing that the enzyme is less thermostable when compared to the one studied herein. Also the difference could be attributed to the fact that two enzymes might have different primary structure. The Gibbs free energy of a substance results from the stabilizing forces present in a protein structure.

Thermal denaturation of enzymes also results in an increase in entropy. This results in positive entropies of activation of denaturation, $\Delta \mathrm{S}_{(\mathrm{D})}$, because the randomness or disorder is increased in the transition from ground state to the unstable intermediate state $(\mathrm{U})$, but $\alpha$-amylases from pearl millet had negative entropy which revealed that the enzyme was in more ordered state (Tables I and II). The negative values for change in entropy could have some implications which include; compactation of the protein, ordering of water molecules in the vicinity of the hydrophobic residues and possible aggregation during denaturation (Gummadi, 2003; Marin et al., 2003). A similar trend was observed in peroxidase, lipoxygenase and polyphenol oxidase from white yam (Eze et al., 2010) and xylanase from Aspergillus niger (Pal and Khanum, 2011) but the magnitude was higher in enzymes from white yam, showing that they undergo more aggregation and compactation during inactivation. The differences observed here could be as a result of change in the conformation of the enzymes studied (Gouda et al., 2003).

In conclusion, it is obvious from the ongoing that the pearl millet $\propto$ - amylase is thermally stable and also suitable for its application for biotechnological processes but needs to be improved for the maximization of this attribute.

\section{Acknowledgement}

This study was financed by Mr. and Mrs. Agbo D.M of Federal College of Education Eha-amufu, Enugu state. Agbo Henry Chidiebere of electronic Engineering department, UNN who did the typing of the manuscript and also assisted in the technical work.

\section{References}

Ambasht PK and Kharkrang K (2012), Purification and characterization of alpha amylase from seeds of pearl millet, Journal of Protein and Proteomics 3(1): 47-60.

Bernfeld P (1951), Enzyme of starch degradation and synthesis-Advances in Enzymology, Biochemistry 28: 61-68.

Bhatti HN, Madeeha M, Asgher M and Batool N (2006), Purification and thermodynamic characterization of glucose oxidase from a newly isolated strain of Aspergillus niger, Canadian Journal Microbiology 52: 519-524.

Bommarius AS and Broering JM (2005), Established and Novel Tools to Investigate Biocatalyst Stability, Biocatalysis and Biotransformation 23(3/4): 125-139

Chaplin M (2004), The Use of Enzymes in Starch Hydrolys is, http://ww w. ls bu.ac.uk/ biology/enzlech/glucose.html.

Corbishley DA and Miller W (1984), Tapioca Arrow Root and Sago Starches Production In: Starch Chemistry and Technology, Academic Press, New York, PP 469-778.

Damodaran S (2006), Protein Denaturation In: Handbook of food science, technology and engineering, Ed. Hi YH, FL, CRC Press.

Eze SOO, Chilaka FC and Nwanguma BC (2010), Studies on 
Thermodynamics and Kinetics of Thermo-Inactivation of Some Quality-Related Enzymes in White Yam (Dioscorea rotundata), Journal of Thermodynamic and Catalysis 1: 104

Gouda, MD, Singh SA, Rao AA, Thakur MS and Karanth NG (2003), Thermal Inactivation of Glucose Oxidase, The Journal of Biological Chemistry 278(27): 24324-24333

Griffin H, Dintzis FR, Krull L and Baker FL (1984), A microfibril generating factor from the enzyme complex of Trichoderma reesei, Biotechnology and Bioengeneering 26: 269-300.

Gummadi SN (2003), What is the Role of Thermodynamics on Protein Stability?, Biotechnology and Bioprocess Engineering 8: 9-18

Illanes A (1999), Stability of biocatalysts, Electronic Journal of Biocatalysts 2(1): 1-2.

Illanes A, Altamirano C and Wilson L (2008), Homogenous Enzyme Kinetics In: Enzyme Biocatalysis, Ed. Illanes A, Springer, p 146.

Javed MR, Rashid MH, Nadeem H, Riaz M and Perveen R (2009), Catalytic and Thermodynamic Characterization of Endoglucanase (CMCase) from Aspergillus oryzae cmc-1, Applied Biochemistry and Biotechnology 157: 483-97.

Kouadio EP, Konan HK, Dabonne S, Due EA and Kouame LP (2013), Study of Thermal stability of a-Amylase Sourced from Digestive Tract of the Tropical House Cricket, Gryllodes sigillatus: Kinetic and Thermodynamic analysis, Journal of Novel Applied Sciences 2(3): 74-82.

Kumar SR (2008), Structure, Function and Stability of Alpha-Amylase from Jowar (Sorghum Bicolar), Ph.D. Thesis, University of Myrose, p 99.

Lowry OH, Rosebrough NJ, Farr AL and Randall RJ (1951), Protein measurement with the Folin phenol reagent, Journal of Biological Chemistry 193: 265- 275.

Marangoni AG (2003), Enzyme kinetics: A modern approach, John Wiley and Sons, New Jersey, pp $140-157$
Marin E, Sanchez L, Perez MD, Puyol P and Calvo M (2003), Effect of Heat Treatment on Bovine Lactoperoxidase Activity in Skim Milk: Kinetic and Thermodynamic Analysis, Journal of Food Sciences 68(1): 89-93.

Misset O (1993), Stability of Industrial Enzymes In: Stability of Enzymes, Eds. van Den Tweel, W. Hader A and Buitelaar R, Elsevier, Amsterdam, p 111-131.

Mozhaev V (1993), Mechanism-based strategies for protein thermostabilization, Trends in Biotechnology 11: 88-95.

Okolo BN, Ezeogu LI and Mba CN (1995), Production of raw starch digesting Amylase by Aspergillus niger and Bacillus alvei grown on nature sources, Science of Food and Agriculture 69: 109-115.

Pal A and Khanum F (2011), Characterizing and improving the thermostability of purified xylanase from Aspergillus niger DFR-5 grown on solid-state-medium, Journal of Biochemical Technology 2(4): 203-209.

Petsko, GA and Ringe D (2004) Protein structure and function, New Science Press in Association with Sinauer Associates and Blackwell Science, London p 45.

Riaz MR, Perveen MR, Javed H, Nadeem and MH Rashi (2007), Kinetics and Thermodynamic Properties of noval glucoamylase from Humicola sp., Enzyme and Microbial Technology 41: 558-564.

Sanjust, E., Salis, A., Rescigno, N., Curreli, A. and Rinaldi, A. (2004). Xylose production from durum wheat bran: enzyme versus chemical methods, Food science and Technology International 10(1): 11-14.

Saqib AN, Hassan M, Khan FN and Baig S (2010), Thermostability of crude endoglucanase from Aspergillus fumigatus Grown under Solid State Fermentation (SSF) and Submerged Fermentation (SmF), Process Biochemistry 45: 641-646.

Sharma A, Sharma S and Gupta MN (2000), Purification of Wheat Germ Amylase precipitation, Protein Expression and Purification 18: 111-114.

Siddiqui KS, Azhar MJ, Rashid MH and Rajoka MI (1997), Stability and identification of active-site residues of carboxymethylcellulases from Aspergillus niger and Cellulomonas biazotea, Folia Microbiology 42(4): 312-318. 
Tanaka A and Hoshino E (2002), Calcium-binding parameter of Bacillus amyloliquefaciens $\alpha$-amylase determined by inactivationkinetics, Biochemical Journal 364: 635-639.

Thoma JA, Spradlin JE and Dygert S (1971), Plant and Animal Amylases In: The Enzymes, Ed. Boyer PD, $5^{\text {th }}$ Ed., Academic Press, New York, p 115-189.
Warner DA and Knutson CA (1991), Isolation of $\alpha$-Amylase and other starch digesting enzymes from endosperm of germinating maize, Plant Science 78: 143-150.

Wasserman B (1984), Thermostable Enzyme Production, Food Technology 38: 78-88.

Received: 19 December 2016 Revised: 29 December 2016; Accepted: 25 January 2017. 